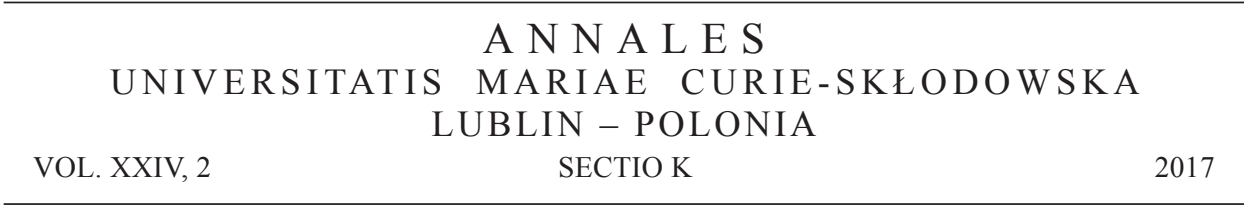

Wydział Ekonomiczno-Socjologiczny Uniwersytetu Łódzkiego

AGNIESZKA MICHALSKA-ŻYŁA, KAMIL BRZEZIŃSKI

\title{
Budżet partycypacyjny jako mechanizm wspótrządzenia miastem
}

Participatory Budget as a Mechanism of Co-Management of the City

\begin{abstract}
ABSTRAKT
Jednym z możliwych sposobów poradzenia sobie ze współczesnym kryzysem demokracji mogą być rozwiązania zmierzające do zwiększania społeczno-politycznej partycypacji obywateli. Rozwiązania te powinny się opierać na założeniach koncepcji governance. Przykładem metody (mechanizmu) włączania obywateli w proces współdecydowania, a tym samym zwiększania ich zaangażowania w kształtowanie polityki miejskiej jest zyskujący coraz większą popularność w polskich samorządach budżet obywatelski. Na ile jednak jest to narzędzie partycypatywne, oparte na rzeczywistym i aktywnym uczestniczeniu mieszkańców w jego realizacji? Celem artykułu jest próba odpowiedzi na tak sformułowane pytanie.
\end{abstract}

Słowa kluczowe: budżet partycypacyjny, zarządzanie publiczne, governance, aktywność obywatelska

\section{WSTĘP}

Opisywany przez wybitnych znawców problematyki [Barber 2003; Putnam 2008] kryzys demokracji sprowadza się nie tyle do zagrożenia wolności różnymi formami totalitaryzmu, co raczej załamania się podstawowego elementu demokratycznego ustroju, jakim jest społeczeństwo demokratyczne. Jak przekonywał Karol Haratyk [2015: 46]: „Kryzys ów nie kryje się w braku wolności jednostki, ale raczej w nadmiarze jej wolności lub też - wyrażając się bardziej precyzyjnie - w nadmiarze wolności negatywnej i niedostatku wolności pozytywnej. Współczesny kryzys demokracji jest więc $\mathrm{w}$ istocie kryzysem centralnej idei demokracji - idei obywatelskości”. Przejawami tego kryzysu, jak dowodził Robert Putnam [2008: 80], jest 
istotny spadek aktywności obywatelskiej w postaci nieuczestniczenia w wyborach oraz braku zainteresowania sferą polityki i przynależnością zarówno do politycznych, jak i społecznych organizacji. Nelson Dias [2014: 21] zwrócił również uwagę na swego rodzaju „demokratyczne rozczarowanie" i kryzys liberalnej demokracji, który jego zdaniem przejawia się m.in. coraz niższym odsetkiem osób biorących udział w wyborach, zwiększającą się nieufnością do polityków i instytucji, a rosnącym poczuciem alienacji politycznej. Zdaniem autora, obywatele coraz częściej mają poczucie, że ich udział w głosowaniu nie ma przełożenia i wpływu na podejmowane przez władze decyzje. Coraz częściej odczuwają również, że nie są reprezentowani przez polityków, a ich rola jako obywateli została ograniczona jedynie do mechanicznego aktu głosowania - wrzucania kartek do urny. Na podobne tendencje występujące na poziomie samorządów lokalnych w Polsce zwrócił uwagę Marcin Gerwin [2012: 25]. Jak podkreślił, pomimo przepisów konstytucyjnych i ustawowych w Polsce nie wykształciła się jeszcze „kultura demokracji” oznaczająca, że mieszkańcy posiadają świadomość bycia suwerenem, a radni, prezydenci i burmistrzowie zdają sobie sprawę, że są jedynie ich przedstawicielami, „bywa natomiast tak, że prezydent miasta uważa się za króla i traktuje miasto niczym swoją prywatną własność" [Gerwin 2012: 26]. Zdaniem autora, kluczowym elementem w kształtowaniu polityk miejskich powinna być zatem partycypacja m.in. w formie referendów lokalnych, konsultacji społecznych oraz budżetów partycypacyjnych [Gerwin 2012: 30]. W opinii Przemysława Filara i Pawła Kubickiego [2012] narzędzia te mogą sprawić, że mieszkańcy będą mogli faktycznie poczuć się współtwórcami miasta.

Warto się zastanowić nad korzyściami wynikającymi z obywatelskiej aktywności. Przyjmuje się, iż jest ona jednym z podstawowych czynników przemian rynkowych i społecznych oraz elementem kształtowania afirmatywnych postaw wobec zmian systemowych, co wydaje się szczególnie istotne w państwach i społeczeństwach, które przechodzily transformację systemową [Stypułkowski 2012: 158-159]. Definiując aktywność obywatelską, Piotr Gliński i Hanna Palska [1997: 365] wskazali, iż „polega ona na wspólnej i świadomej artykulacji, realizacji i obronie interesów (potrzeb, aspiracji) jakiejś grupy społecznej przez jej członków”. Oprócz realizacji funkcji obywatelskich związanych z artykulacją interesów, kontrolą władzy i partycypacją społeczną cechuje się również społecznym charakterem wyrażonym w działaniach zaspokajających różnorodne potrzeby. Choć na ogół autorzy odróżniają aktywność obywatelską od aktywności politycznej i obywatelskiej aktywności indywidualnej, to jak wskazał w innym opracowaniu Piotr Gliński [2006: 58], „oprócz aktywności pozarządowej wyróżnić można co najmniej cztery inne obszary aktywności obywatelskiej: wspólnoty lokalne i samorząd terytorialny; ruchy społeczne, organizacje i ruchy nieformalne; aktywność w partiach i stowarzyszeniach politycznych oraz obywatelską aktywność indywidualną".

1 Sformułowanie oryginalne ,democratic disenchantment”. 
Dokonując nawet pobieżnego przeglądu wyników badań społecznego zaangażowania Polaków, należy skonstatować, iż lokuje się ono na niskim poziomie, a dominującą postawą jest bierność. Największe deficyty partycypacji obywatelskiej dotyczą przede wszystkim różnych form działań podejmowanych na rzecz środowiska lokalnego. Badania CBOS $[2011,2012]$ zrealizowane na ogólnopolskiej próbie pokazują, iż w nieodpłatne działania na rzecz swojej miejscowości zamieszkania podjął w ciągu ostatniego roku średnio co piąty ankietowany, chociaż przeszło połowa badanych przyznaje się do takich doświadczeń. Również wyniki Diagnozy Społecznej 2011 [Sułek 2011] jednoznacznie pokazują, iż ludzie, którzy wykazują pozytywną postawę wobec zaangażowania w prace na rzecz swoich społeczności lokalnych, stanowią w Polsce nieliczną kategorię. W roku 2011 działania takie podejmowało niespełna $16 \%$ Polaków. Podobne rezultaty, świadczące o bierności mieszkańców miast średniej wielkości w województwie łódzkim, uzyskała współautorka niniejszego opracowania [Michalska-Żyła 2015]. Analizując w swoich badaniach aktywność społeczno-polityczną, ustaliła, iż badani angażują się w nieco ponad jeden rodzaj działania spośród siedmiu, o jakie pytano. Dominującym typem zachowania był zatem brak zaangażowania $\mathrm{w}$ działania na rzecz lokalnego środowiska.

Próby rozwiązania problemu niskiego poziomu społeczno-politycznego uczestnictwa wymagają podjęcia zakrojonych na szeroką skalę przemian demokracji. Transformacja demokracji przedstawicielskiej w kierunku demokracji uczestniczącej wydaje się słuszną i postulowaną orientacją. Tworzenie rozwiązań zapewniających wzrost obywatelskiego zaangażowania w procesy decyzyjne szczególnie na poziomie lokalnym jest realizowane w nowych partycypatywnych koncepcjach zarządzania publicznego [Marks-Krzyszkowska 2013, 2016; Oramus 2015]. Takie rozwiązania wpisują się w koncepcję ,silnej demokracji” lansowanej przez Benjamina Barbera [1997]. Opiera się ona na idei samorządności i współpracy obywateli, którzy są powiązani wspólnymi celami i działaniami wynikającymi z obywatelskich postaw i kompetencji oraz funkcjonowaniu instytucji to uczestnictwo gwarantujących. „Silna demokracja potrzebuje obywateli, obywatelom zaś potrzebne jest społeczeństwo obywatelskie" [Barber 1997: 373]. Idei tej przyświeca założenie dotyczące przemian instytucjonalnej strony demokracji. Według niego obywatele staną się bardziej aktywnymi elementami procesu politycznego, gdy zaczną dostrzegać, iż są w stanie wpływać na środowisko, w którym żyją [Haratyk 2015: 48].

Jednym ze sposobów zwiększenia partycypacji mieszkańców w procesie współzarządzania miastem i decydowania o alokacji środków budżetowych jest budżetowanie partycypacyjne, które z coraz większym rozmachem jest realizowane przez samorządy lokalne w Polsce. Celem niniejszego artykułu jest analiza łódzkiego budżetu partycypacyjnego, a dokładniej próba skonfrontowania zasad, na których się on opiera z powszechnie przyjmowanymi i akceptowanymi kryteriami budżetów partycypacyjnych w Polsce. Innymi słowy dokonana zostanie ocena sposobu wdrażania łódzkiego budżetu obywatelskiego w świetle standardów opracowanych przez Pracownię badań i innowacji społecznych „Stocznia”. Wybór miasta jest 
nieprzypadkowy, gdyż rozwiązania przyjęte w Łodzi są często pokazywane jako przykład dobrej praktyki. Tak między innymi oceniono łódzki budżet obywatelski w publikacji przygotowanej przez Fundację Gospodarki i Administracji Publicznej pt. Partycypacja społeczna w Polsce. Atlas dobrych praktyk. Mając na uwadze pozytywne opinie na temat łódzkiego budżetu, postanowiono przyjrzeć się jego realizacji i sposobowi wdrożenia, tym samym próbując odpowiedzieć na pytanie, czy i w jakim stopniu jest on rzeczywiście partycypacyjny?

\section{W KIERUNKU PARTYCYPATYWNYCH METOD ZARZĄDZANIA SFERĄ PUBLICZNĄ}

Rozwiązania zmierzające do zwiększania społeczno-politycznej partycypacji obywateli przejawią się w różnych formach, w tym, co jest szczególnie istotne ze względu na podjętą w niniejszym artykule problematykę, w tworzeniu takich rozwiązań dla polityki publicznej, aby w większym stopniu realizowała ona inkluzyjny model zarządzania. Jego realizacja jest związana nie tylko z rodzajem formułowanych celów (mających społeczny, publiczny i niewykluczający charakter), lecz także z aktywnym uczestniczeniem obywateli w procesie ich definiowania i realizowania. Taka wizja współczesnego zarządzania sferą publiczną jest bliska modelowi governance, którego synonimami są: współzarządzanie publiczne, partycypacyjne zarządzanie publiczne lub zarządzanie interaktywne. Ustalenia przyjęte w ramach omawianej koncepcji zarządzania publicznego akcentują potrzebę przekazania przez podmioty publiczne (np. samorządy lokalne) części swoich kompetencji innym podmiotom, nawiązywanie różnych form współpracy, a także postępującą, opartą na zaufaniu, współzależność przy jednoczesnym zachowaniu autonomii [Rhodes 1997, 2007; Stoker 1998, za: Marks-Krzyszkowska 2016]. Wyrazem partycypacyjnej formy zarządzania na poziomie lokalnym jest local governance, który można określić jako elastyczny model podejmowania decyzji na podstawie luźnych powiązań pomiędzy jednostkami samorządu terytorialnego a społeczeństwem na poziomie lokalnym [Łukomska-Szarek, Włóka 2013: 210]. W praktyce oznacza to decentralizację uprawnień decyzyjnych, nie tylko pomiędzy różnymi szczeblami administracji samorządowej, lecz także bezpośrednie włączenie w ten proces obywateli, zarówno indywidualnych, jak i zorganizowanych w różnego rodzaju grupy. Ów nowy wymiar realizacji polityki publicznej oznacza zatem zmianę rozwiązań w kierunku od administrowania opartego na biurokratycznych standardach do współrządzenia opartego na sieciowym charakterze relacji między różnymi podmiotami zaangażowanymi $\mathrm{w}$ ten proces. Podmiotami a zarazem kreatorami działań w sektorze publicznym mogą być, oprócz podmiotów państwowych, reprezentanci społecznego czy prywatnego sektora, do których można zaliczyć organizacje pozarządowe, przedstawicieli sfery biznesu oraz indywidualnych obywateli. Bez wątpienia jednak główną rolę w tworzeniu polityki publicznej przypisuje się agendom rządowym, a na poziomie lokalnym władzom różnego szczebla samorządu [Marks-Krzyszkowska 2016]. Pozytywnym efektem 
tego rodzaju partnerskiej kooperacji jest to, iż wszyscy aktorzy zyskują dodatkową zdolność do działania wynikającą z połączenia zasobów, umiejętności i zamierzeń dla osiągnięcia pożądanego rezultatu [Oramus 2015: 190].

Podmioty sektora publicznego zaczynają się zatem charakteryzować coraz większym pluralizmem, zarówno jeśli chodzi o ich grono, podlegające znacznej heterogenizacji, zakres ich działania, jak i metody, przy których wykorzystaniu definiują oraz realizują cele publiczne. Cele te odnoszą się rzecz jasna do spraw, które można zdefiniować jako „każdy przejaw aktywności władzy publicznej (jej organów), osób pełniących funkcje publiczne i samorządów oraz już tylko niektóre działania innych osób, jednostek organizacyjnych, a to tylko takie, które wiążą się z wykonywaniem zadań publicznych, przy jednoczesnym dysponowaniu majątkiem publicznym, przez który należy również rozumieć środki publiczne w rozumieniu przepisów o finansach publicznych" [Luterek 2010: 147-148].

Proponowane rozwiązania oparte na obywatelskiej partycypacji wiążą się z próbą odpowiedzi na rosnące oczekiwania wobec jakości i podaży usług publicznych realizowanych w sytuacji ograniczoności zasobów finansowych, a często także organizacyjnych i kompetencyjnych potrzebnych do ich zaspokojenia [zob. Lewenstein 2010]. Efektem podejmowanego współdziałania ma być zatem skuteczna realizacja działań oraz poprawa jakości funkcjonowania sfery publicznej. Istotnym zagadnieniem jest, jak się wydaje, wykorzystanie różnorodnych technik nakłaniania, perswazji i przekonywania w celu zwiększenia sieciowego współdziałania różnorodnych podmiotów, co jak przekonywała Patrycja J. Suwaj [2010: 61], potęguje efektywność zarówno w wymiarze kolektywnym, jak i indywidualnym.

Istotnym problemem, jaki wyłania się przy tworzeniu partycypatywnych metod zarządzania sferą publiczną, jest po pierwsze, ustalenie zakresu spraw, które mogą być realizowane przy współzaangażowaniu różnych podmiotów, po drugie, określenie wzajemnych relacji między podmiotami oraz po trzecie, tworzenie skutecznych mechanizmów owo współdziałanie potęgujących. „Rządzenie w ujęciu governance zawsze odbywa się w formie interaktywnych, a nie imperatywnych relacji, gdyż zakłada się brak posiadania całościowej wiedzy oraz wystarczających zasobów do zdominowania procesu decyzyjnego przez jeden podmiot. $Z$ tego względu konieczne jest zastosowanie różnych form partnerstwa: od delegowania przez władzę zadań innym aktorom (zlecający nie ma pewnych informacji odnośnie spodziewanego zachowania wykonawcy), przez wewnątrzorganizacyjne negocjacje (istnieje ryzyko różnego postrzegania ostatecznych ustaleń przez poszczególne podmioty), po systemową koordynację" [Oramus 2015: 189]. Istotnym zagadnieniem jest ponadto klimat społeczny i polityczny oparty na pozytywnych postawach partycypacyjnych zarówno przedstawicieli lokalnej władzy akceptujących zwiększanie zakresu uczestnictwa innych podmiotów, jak i obywateli aprobujących określone metody i formy współpracy w realizacji polityki publicznej.

Starając się realizować interaktywne metody zarządzania sferą publiczną władze samorządowe dysponują różnymi narzędziami zapewniającymi włączanie różnych 
podmiotów, w tym indywidualnych obywateli, funkcjonujących w lokalnej przestrzeni $\mathrm{w}$ procesy kreowania lokalnej polityki publicznej. Jednym $\mathrm{z}$ takich rozwiązań, które w Polsce stało się niezwykle popularne, choć zarazem wzbudza wyraźne kontrowersje, jest budżetowanie partycypacyjne.

\section{BUDŻET PARTYCYPACYJNY JAKO NARZĘDZIE PARTYCYPATYWNE}

Budżetowanie partycypacyjne jest określane mianem instrumentu współuczestnictwa obywateli wywodzącego się z koncepcji local governance, utożsamianej ze współzarządzaniem na poziomie lokalnym [Łukomska-Szarek 2013]. W literaturze przedmiotu jest definiowane jako ,proces decyzyjny, w ramach którego mieszkańcy współtworzą budżet danego miasta, tym samym współdecydują o dystrybucji określonej puli środków publicznych" [Kębłowski 2013: 8]. Zdaniem Nelsona Diasa [2014], budżet partycypacyjny jest jedną z praktyk, która przyczynia się do upodmiotowienia obywateli i zwiększenia zaufania między politykami a obywatelami. Jak zauważył autor, budżet partycypacyjny i podobne mu eksperymenty w ostatnich latach zostały pozytywnie przyjęte $\mathrm{w}$ wielu częściach świata i przyczyniają się do zwiększania zaangażowania obywateli w kształtowanie polityk miejskich. W opinii innych autorów [Sintomer, Herzberg, Rocke 2014] praktyka ta jest jednym z lepszych mechanizmów partycypacyjnych ostatnich 20-30 lat. Opinie te potwierdzają liczby dowodzące zwiększającej się popularności budżetów obywatelskich. Mechanizm, który został zainicjowany w 1989 roku w brazylijskim Porto Alegre [Kębłowski 2013: 11], dzisiaj jest znany i stosowany na całym świecie. Z ostrożnych szacunków wynika, że w 2013 roku zrealizowano między 1300 a 2700 budżetów partycypacyjnych, w tym od około 600 do 1100 w Ameryce Łacińskiej, między 470 a 1300 w Europie, a około 60-100 w Azji oraz między 100 a 200 w Afryce [Kębłowski 2013: 29].

Pomimo postawionej niespełna kilka lat temu diagnozy dotyczącej braku kultury demokratycznej [Gerwin 2012], w ostatnim czasie w polskich miastach można dostrzec znaczącą jakościową zmianę przejawiającą się w próbach włączania mieszkańców w procesy decyzyjne. Jak zauważył Wojciech Kębłowski [2013: 6]: „Gdy w 2011 roku w Sopocie doprowadzono do realizacji pierwszego w Polsce budżetu partycypacyjnego, mało kto się spodziewał, że ten odosobniony eksperyment wkrótce zyska status jednej z najpopularniejszych w naszym kraju inicjatyw mających na celu włączanie mieszkańców w proces zarządzania miastami”. Na portalu budzetyobywatelskie.pl prowadzonym przez Fundację Instytutu Myśli Nowoczesnej można znaleźć informacje, z których wynika, że w roku 2013 realizowanych było 8 budżetów partycypacyjnych, w 2014 już 48, a w 2015 aż 80 . Z kolei z informacji zamieszczonych na portalu bp.partycypacjaobywatelska.pl prowadzonym przez Pracownię badań i innowacji społecznych „Stocznia” wynika, że w 2015 roku zrealizowano w Polsce aż 143 budżety obywatelskie. Ta zwiększająca się popularność 
budżetów partycypacyjnych jest zastanawiająca i budzi zarazem wiele kontrowersji. Swoista „moda” na budżety partycypacyjne jest jednak szeroko komentowana [Kębłowski 2014: 5]. Z jednej strony bowiem podkreśla się, że przedsięwzięcia tego typu sprzyjają tworzeniu społeczności lokalnej, z drugiej strony natomiast krytykuje się je za formę plebiscytu, w którym decyduje się jedynie o nieznacznej części budżetu miasta, co ma zająć mieszkańców i odwrócić ich uwagę od krytyki władz. Zastanawiające jest także to, czy wzrost popularności budżetów partycypacyjnych wynika z rzeczywistej chęci włodarzy miejskich do włączenia mieszkańców w procesy decyzyjne zgodne z koncepcją governance. Czy budżety stanowią raczej swego rodzaju „modny gadżet”, wykorzystywany do działań promocyjnych, którego efekty dają o sobie znać zwłaszcza przed wyborami samorządowymi? A może stanowią one swojego rodzaju „metodę na ruchy miejskie”, umożliwiając pacyfikację ich żądań [Kębłowski 2014: 5]? Na kontrowersje związane z polskimi budżetami partycypacyjnymi zwróciły również uwagę Agata Bluj i Ewa Stokłuska [2015: 7], pisząc we wstępie do swojej publikacji: „Widmo budżetu partycypacyjnego krąży po Polsce. Używamy słowa »widmo« świadomie, bo niestety często procesy, które określa się tym terminem (lub terminem »budżet obywatelski«), odbiegają dość daleko nie tylko w swojej formie, ale i w założeniach od pierwowzoru mechanizmu, który uruchomiono po raz pierwszy w 1989 roku w brazylijskim Porto Alegre i który wniósł nowe spojrzenie do myślenia o tym, jak bardzo bezpośrednia może być lokalna demokracja i czy »zwykli« mieszkańcy mogą osobiście decydować o publicznych wydatkach”.

Aby móc odpowiedzieć na pytanie, w jakim stopniu polskie budżety są partycypacyjne i na ile są one rzeczywistym instrumentem współrządzenia, należy zdefiniować budżet partycypacyjny i określić, jakie powinien spełniać kryteria. Zadanie to jest jednak dość trudne, gdyż jak zauważają niektórzy autorzy [Sintomer, Herzberg, Rocke 2014: 29], procedury nazywane $\mathrm{w}$ jednym miejscu budżetem partycypacyjnym w innym mieście za takie mogą nie zostać uznane. Warunkiem, jaki należy uznać za podstawowy dla tego rodzaju przedsięwzięć, jest możliwość współdecydowania przez mieszkańców o sposobie wydatkowania pewnej puli środków publicznych [Sintomer, Herzberg, Rocke 2014: 29; Kębłowski 2013: 8]. Pozostałe kryteria wyróżnienia budżetów partycypacyjnych koncentrują się na kilku zasadniczych kwestiach. Po pierwsze, środki finansowe, o których przeznaczeniu decydują mieszkańcy, są z góry określone. Po drugie, działania i przedsięwzięcia finansowane w ramach tej procedury powinny obejmować swym zasięgiem zarówno poziom ogólnomiejski, jak i dzielnicowy. Po trzecie, procedura budżetu partycypacyjnego powinna być powtarzana corocznie, jest bowiem wymagana pewna cykliczność. Warunek czwarty koncentruje się na uwzględnieniu aspektu deliberatywnego. Obywatelom biorącym udział w tej procedurze powinna zostać stworzona możliwość swobodnej dyskusji i wymiany opinii.

I wreszcie warunek piąty odnosi się do wiążącego charakteru wyników głosowania w ramach budżetu partycypacyjnego [Kębłowski 2013: 8]. Na podobne wymogi, które powinien spełnić budżet partycypacyjny, zwróciły również uwagę 
A. Bluj i E. Stokłuska [2015: 8] Autorki wskazały przy tym zasadniczy cel tej praktyki, którym jest włączenie w procesy zarządzania gminą jej mieszkańców oraz stworzenie przestrzeni do dyskusji i wymiany opinii na temat priorytetów własnej społeczności w szerokim gronie jej członków. Budżet partycypacyjny powinien mieć także inkluzyjny charakter, a więc dawać każdemu mieszkańcowi możliwość zgłaszania własnych propozycji. Mechanizm ten powinna ponadto charakteryzować przejrzystość i jawność procedur [Bluj, Stokłuska 2015: 8]. Uporządkowany katalog zasad, którymi powinny się charakteryzować budżety partycypacyjne, został przygotowany i opublikowany przez Pracownię badań i innowacji społecznych „Stocznia”. W dokumencie zatytułowanym Standardy procesów budżetu partycypacyjnego w Polsce można przeczytać między innymi to, że „na proces budżetu partycypacyjnego składa się zestaw zasad i wartości, które determinują autentyczne współdecydowanie przez mieszkańców o kształcie lokalnej wspólnoty oraz stanowią wyraz nowatorskiego, otwartego na głos członków lokalnej społeczności sposobu myślenia o jej rozwoju" [Standardy procesów budżetu partycypacyjnego w Polsce 2015: 9]. Na wspomniany zbiór kluczowych zasad składają się następujące elementy:

- wiążący wynik procedury,

- przejrzystość i jawność procedury,

- otwartość i inkluzywność procesu,

- zapewnienie przestrzeni do deliberacji (debaty) z udziałem mieszkańców,

- wspieranie aktywności mieszkańców,

- myślenie długofalowe [Standardy procesów budżetu partycypacyjnego w Polsce 2015; Kraszewski, Mojkowski 2014].

Mając na uwadze powyższy katalog zasad, które powinny uwzględniać budżety partycypacyjne, spróbujemy przyjrzeć się łódzkiemu budżetowi obywatelskiemu ${ }^{2}$ i ocenić, czy w istocie jest on partycypacyjny i czy spełnia warunki skutecznego mechanizmu współrządzenia. Literatura przedmiotu dostarcza przykładów ewaluacyjnych analiz polskich budżetów partycypacyjnych. Badania obejmujące większość polskich budżetów partycypacyjnych prowadził między innymi Wojciech Kębłowski [2014]. Do oceny wykorzystał zarówno kryteria wynikające z definicji budżetu partycypacyjnego, w znacznym stopniu zbieżne z zasadami opracowanymi przez „Stocznię" oraz wybrane kryteria ilościowe 4 . Z przeprowadzonych przez autora analiz wynika, że sposób realizacji większości polskich budżetów partycypacyjnych opiera się na stosunkowo podobnym modelu, który został oceniony raczej negatywnie: „Budżet partycypacyjny po polsku opiera się na zasadach, które zazwyczaj są przygotowy-

2 W Łodzi, podobnie jak i w części innych polskich miast jest stosowana nazwa „budżet obywatelski”, zamiast ,partycypacyjny”.

3 Wśród kryteriów tych znalazły się: spotkania mieszkańców, jasno określone środki finansowe, cały obszar gminy/miasta, wiążący charakter, cykliczność.

4 Pełen opis wykorzystanych kryteriów do ewaluacji można znaleźć w publikacji W. Kębłowskiego [2014: 11]. 
wane odgórnie, bez konsultacji z mieszkańcami. Ich opracowanie, często w ekspresowym tempie, zdaje się odbywać pod silnym (a zarazem mało produktywnym) wpływem doświadczeń innych miast. W modzie na budżet partycypacyjny brakuje refleksji nad celowością kopiowania rozwiązań z innego kontekstu społecznego czy ekonomicznego". Ponadto po ogłoszeniu przyjętych zasad sporadycznie są organizowane spotkania, na których uczestnicy mogliby podjąć współpracę przy opracowaniu własnych postulatów i projektów. Co więcej, jeżeli już jakieś spotkania są zwoływane, to mają charakter informacyjny i są pozbawione jakiejkolwiek mocy decyzyjnej [Kębłowski 2014: 36]. Nie oznacza to, iż w Polsce nie można znaleźć pozytywnych przykładów takich realizacji budżetu partycypacyjnego, w których władze miast byłyby bardziej wrażliwe na potrzeby i głosy mieszkańców. Wśród tych pozytywnych przykładów obok Dąbrowy Górniczej, Gdańska-Wrzeszcza wymieniana jest również Łódź [Kębłowski 2014: 36].

\section{ŁÓDZKI BUDŻET OBYWATELSKI - OPIS PROCEDURY5}

Do tej pory w Łodzi zrealizowano trzy edycje budżetu obywatelskiego [2014, 2015 i 2016] $]^{6}$. Decyzja o wprowadzeniu przez władze miasta tego mechanizmu włączającego mieszkańców w proces współdecydowania o mieście została podjęta w maju w 2012 roku, kiedy to Rada Miasta wraz z Prezydent Miasta Hanną Zdanowską przyjęła uchwałę o rozpoczęciu działań mających na celu opracowanie szczegółowej procedury dla łódzkiego budżetu obywatelskiego. Kolejnym krokiem było zarządzenie prezydent miasta w sprawie powołania zespołu ds. opracowania zasad funkcjonowania i wdrożenia budżetu. Zespół liczył 23 członków, a w jego składzie znaleźli się przedstawiciele Rady Miejskiej, organizacji pozarządowych, rad osiedli, Urzędu Miasta Łodzi, a także Uniwersytetu Łódzkiego [Gałecki 2013]. W wyniku prac zespołu opracowano szczegółową procedurę wraz ze stosownymi zasadami $^{7}$, a w 2013 roku rozpoczęła się realizacja I edycji. Od tego momentu rok rocznie łódzki budżet obywatelski jest przeprowadzany według kilku etapów ${ }^{8}$ : [2016].

5 Opis procedury łódzkiego budżetu obywatelskiego znajduje się również w artykule K. Brzezińskiego

$6 \mathrm{~W}$ czasie opracowywania niniejszego tekstu trwała realizacja czwartej edycji.

7 Szczegółowe informacje na temat opracowywania zasad łódzkiego budżetu obywatelskiego można znaleźć w tekście A. Gałeckiego [2013].

8 W każdym roku realizacja łódzkiego budżetu przebiega według przedstawionego schematu, natomiast $\mathrm{w}$ wyniku ewaluacji pewnym zmianom ulegają sposoby realizacji poszczególnych etapów, np. z roku na rok upraszczany jest formularz zgłoszeniowy propozycji zadań. 


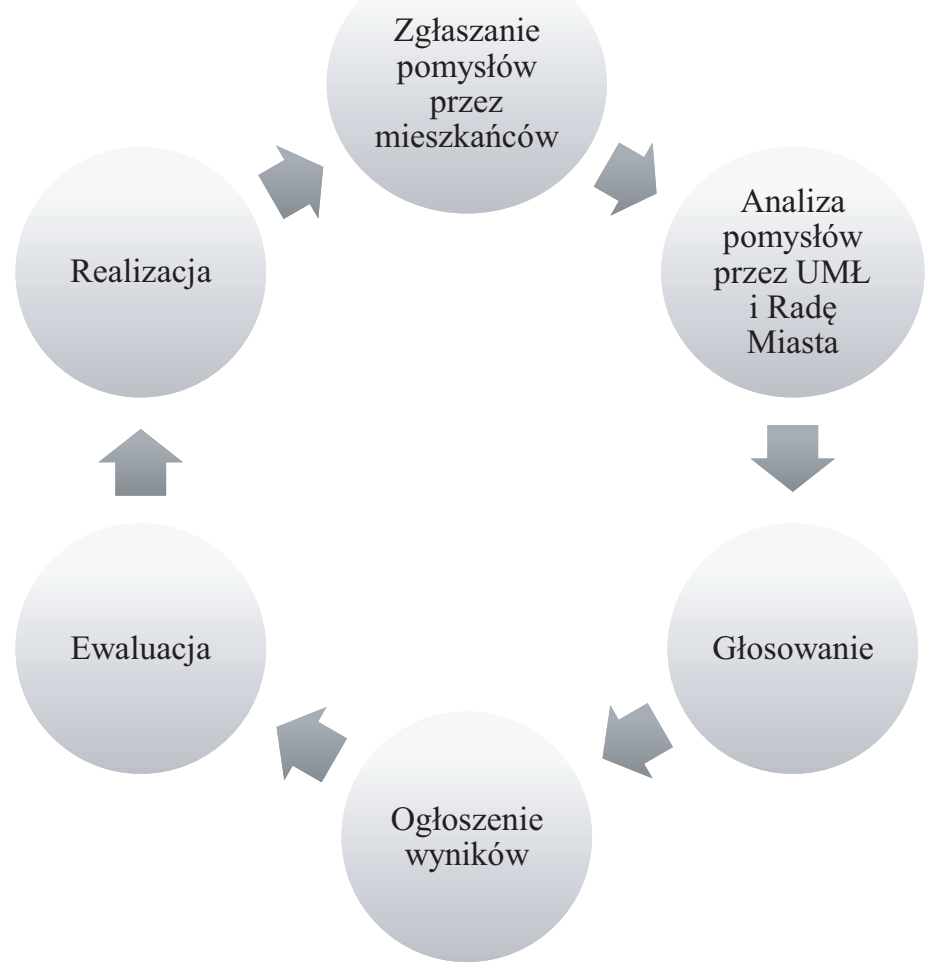

Wykres 1. Schemat realizacji łódzkiego budżetu obywatelskiego.

Źródło: opracowanie własne.

Realizacja danej edycji budżetu obywatelskiego rozpoczyna się od upublicznienia informacji przez Urząd Miasta Łodzi o planowanej realizacji budżetu, harmonogramie i obowiązujących zasadach. W celu poinformowania mieszkańców o idei budżetu, zasadach funkcjonowania i ewentualnych zmianach w stosunku do edycji wcześniejszych z mieszkańcami są prowadzone spotkania informacyjne, które zwykle są realizowane przez organizację pozarządową. W I i II edycji spotkania odbyły się we wszystkich jednostkach pomocniczych miasta, tzw. osiedlach. W sumie w ramach dwóch pierwszych edycji zrealizowano po 36 spotkań $^{9} \mathrm{z}$ mieszkańcami oraz dodatkowo spotkania z przedstawicielami NGO, radami osiedli oraz osobami głuchoniemymi. W ramach III edycji zorganizowano pięć tzw. spotkań rejonowych jedno dla każdej dzielnicy miasta oraz cztery spotkania tematyczne, a także trzy dla wybranych grup interesariuszy. Z kolei w IV edycji mieszkańcom zaproponowano kilka spotkań w formie tzw. maratonów pisania wniosków. Maratony to spotkania organizowane przez jedno z łódzkich stowarzyszeń, w ramach których mieszkań-

\footnotetext{
9 Zgodnie z liczbą osiedli w Łodzi.
} 
com zapewniono pomoc w przygotowaniu wniosków oraz stworzono przestrzeń do wymiany opinii na temat głównych problemów, które mogłyby zostać zniwelowane przez zadania mogące zostać zgłoszone do budżetu.

W trakcie kampanii informacyjno-promocyjnej mieszkańcom umożliwia się także składanie własnych propozycji zadań do budżetu. Formularze zgłoszeniowe należy złożyć w Urzędzie Miasta Łodzi do końca maja, a przygotować je może każdy mieszkaniec miasta, niezależnie od adresu meldunkowego, a także wieku ${ }^{10}$. Jedynym warunkiem jest poprawne wypełnienie formularza wniosku oraz uzyskanie piętnastu podpisów poparcia od innych mieszkańców Łodzi. Propozycje zadań w trzech dotychczasowych edycjach można było składać w podziale na tzw. zadania lokalne - dotyczące potrzeb mieszkańców jednej z pięciu dzielnic, bądź ogólnomiejskie, wychodzące naprzeciw interesom mieszkańców przynajmniej dwóch dzielnic lub całego miasta. Każdy z mieszkańców może złożyć dowolną ilość propozycji zadań. W IV edycji zadania lokalne zastąpiono zadaniami osiedlowymi, chcąc tym samym uprzywilejować mieszkańców mniejszych osiedli, których propozycje zadań przepadały w głosowaniu ze względu na małą liczbę ich mieszkańców, a tym samym i oddawanych głosów.

Drugi etap obejmuje analizę formalno-prawną zgłoszonych pomysłów i ich ocenę pod kątem gospodarności dokonywaną przez Urząd Miasta Łodzi oraz Doraźną Komisję ds. Budżetu Obywatelskiego Rady Miejskiej. Poszczególne komórki urzędu sprawdzają, czy proponowane zadania wpisują się w kompetencje miasta oraz czy na obszarze, którego dotyczy projekt zgłaszany przez mieszkańca, nie zaplanowano wcześniej podobnych lub innych działań. W tym miejscu warto zaznaczyć, że urzędnicy ani radni nie ingerują w treści i pomysły mieszkańców, sprawdzają jedynie prawne możliwości ich realizacji, a ostateczną decyzję pozostawiają mieszkańcom, którzy wybierają poszczególne zadania w trakcie głosowania.

Głosowanie, będące trzecim etapem, trwa zwykle kilka dni i odbywa się pod koniec września. Podobnie jak w przypadku zgłaszania propozycji głosować może każdy mieszkaniec Łodzi (niezależnie od adresu meldunkowego). Jedyną różnicą jest konieczność posiadania ukończonych 16 lat. Głosować można za pomocą internetu, poczty bądź tradycyjnie w wyznaczonych lokalach wyborczych. Każdy z głosujących może wskazać pięć zadań lokalnych ${ }^{11}$ i pięć zadań ogólnomiejskich, które w jego opinii powinny zostać zrealizowane.

Po zliczeniu wszystkich głosów wyniki są podawane do publicznej wiadomości (etap 4). Do realizacji są kierowane wszystkie te projekty, które uzyskają największą liczbę głosów i których koszty zmieszczą się w przeznaczonej puli pieniędzy. W ramach I edycji mieszkańcy mieli do rozdysponowania kwotę 20 milionów złotych, z czego na każdą z pięciu dzielnic przeznaczono 3 miliony (zadania lokalne), a pozostałe 5 na

\footnotetext{
${ }^{10}$ Propozycje własnych zadań do budżetu obywatelskiego mogą składać zatem np. studenci, którzy w Łodzi mieszkają tymczasowo na okres trwania studiów albo młodzież szkolna (gimnazjaliści, licealiści).

11 W IV edycji osiedlowych.
} 
zadania ogólnomiejskie. Z kolei w II, III i IV edycji kwota budżetu obywatelskiego wynosiła 40 milionów złotych, co umożliwiło podwojenie kwot przeznaczanych na zadania lokalne (6 milionów) i ogólnomiejskie (10 milionów). W IV edycji kwotę nieco ponad 30 milionów przeznaczono na zadania osiedlowe, podział kwot między poszczególne osiedla określono za pomocą wzoru uwzględniającego liczbę mieszkańców.

Piątym etapem realizowanym zwykle pod koniec każdego roku jest ewaluacja danej edycji budżetu obywatelskiego. W tym czasie każdy mieszkaniec może zgłosić własne propozycje zmiany dotychczasowej procedury, które mogłyby usprawnić cały proces bądź jego poszczególne elementy. Wspomniana rezygnacja z zadań lokalnych (dzielnicowych) i zamiana ich na zadania osiedlowe jest m.in. wynikiem uwag zgłaszanych przez mieszkańców. Natomiast zakończeniem danej edycji (etap 6) jest ukończenie realizacji wszystkich zadań, które zostały wybrane przez osoby głosujące.

\section{ŁÓDZKI BUDŻET OBYWATELSKI A STANDARDY BUDŻETÓW PARTYCYPACYJNYCH}

Zaprezentowane zasady realizacji łódzkiego budżetu obywatelskiego zostaną skonfrontowane $\mathrm{z}$ opisanymi wcześniej standardami budżetów partycypacyjnych, co pozwoli ustalić, czy łódzka wersja spełnia opisywane w literaturze przedmiotu kryteria. Zgodnie $\mathrm{z}$ treściami zawartymi w zarządzeniach prezydent miasta Łodzi dotyczących poszczególnych edycji budżetu obywatelskiego celem tak prowadzonych konsultacji ${ }^{12}$ jest m.in. „dokonanie przez mieszkańców miasta Łodzi, którzy ukończyli 16 lat, wyboru zadań do budżetu obywatelskiego spośród tych propozycji, które zostały pozytywnie zweryfikowane" [Zarządzenie 3971/VI/13 2013, Zarządzenie 3837/VI/14 2014, Zarządzenie 644/VII/15 2015, Zarządzenie 2914/VII/16 2016]. Większość zadan ${ }^{13}$, które do tej pory wybrali mieszkańcy w trakcie głosowań w poszczególnych edycjach łódzkiego budżetu, została bądź jest realizowana przez władze miasta. Uznać zatem można, że łódzka praktyka spełnia jedno z istotnych kryteriów budżetu partycypacyjnego, w myśl którego wyniki procedury powinny być wiążące dla organów miasta [Standardy procesów budżetu partycypacyjnego w Polsce 2015: 9]. Wybory mieszkańców mają zatem realne przełożenie na decyzje $\mathrm{i}$ ich realizację. Udział mieszkańców w procesie zarządzania miastem nabiera zatem realnego kształtu, co powinno w założeniu przyczynić się do poprawy jego efektywności, a w konsekwencji jakości życia łódzkiej społeczności. Zgodnie z drugą zasadą, proces realizacji budżetu partycypacyjnego powinien przebiegać wedle przejrzystych i znanych mieszkańcom reguł [Standardy procesów budżetu partycy-

${ }^{12}$ Zgodnie z zarządzeniami prezydent miasta Łodzi budżet obywatelski jest traktowany jako forma konsultacji społecznych.

${ }^{13}$ Wyjątek stanowi jedynie zadanie dotyczące „Ogrodów Karskiego”, tj. parku, który miał powstać na jednym z łódzkich osiedli przy ulicy Ogrodowej. Proponowane zadanie mieszkańcy wybrali w ramach II edycji łódzkiego budżetu, ale władze zrezygnowały z jego realizacji, gdyż okazało się, że działka, na której miał powstać park, ma już inne przeznaczenie. 
pacyjnego w Polsce 2015: 9]. Odnosząc się do wyżej opisanej procedury łódzkiego budżetu obywatelskiego uzasadnione wydaje się stwierdzenie, że jest ona klarowna i przejrzysta, a tym samym zgodna z zasadą przejrzystości i jawności. Władze miasta, wspólnie z organizacjami pozarządowymi odpowiedzialnymi za przeprowadzenie spotkań informacyjnych z mieszkańcami, starają się zapoznać jak największą liczbę mieszkańców z zasadami budżetu oraz zachęcają ich do przygotowywania własnych propozycji zadań. Informacje o budżecie obywatelskim mieszkańcy mogą otrzymać w trakcie organizowanych spotkań na stronie internetowej UMŁ oraz stronie prowadzonej przez organizację pozarządową odpowiedzialną za organizację spotkań z mieszkańcami ${ }^{14}$. Aby wesprzeć mieszkańców w procesie przygotowywania własnych zadań do budżetu, prowadzony jest też punkt konsultacyjny przez jedną z organizacji pozarządowych, a w poszczególnych komórkach UMŁ oddelegowani są urzędnicy do kontaktów z mieszkańcami. Dodatkowo w lokalnych mediach bardzo często pojawiają się informacje o kolejnych etapach realizacji budżetu.

Powyżej opisane działania dowodzą również, że łódzki budżet obywatelski spełnia także trzecią z kluczowych zasad budżetu partycypacyjnego, a mianowicie kryterium otwartości i inkluzyjności. Przedstawione działania potwierdzają, że organizatorzy łódzkiego budżetu starają się dotrzeć do jak najszerszego grona odbiorców, a także próbują zapewnić odpowiednie wsparcie dla osób chcących przygotować własne propozycje zadań (punkt konsultacyjny, oddelegowani urzędnicy, spotkania z mieszkańcami). W tym miejscu warto przypomnieć, że w łódzkim budżecie obywatelskim mogą brać udział również osoby, które nie są zameldowane w mieście, ale aktualnie w nim mieszkają, stając się realnymi użytkownikami miejskiej przestrzeni. Zastosowane kryterium dowodzi znacznej inkluzyjności realizowanej procedury.

Czwarta zasada wiąże się z organizacją spotkań z mieszkańcami, którzy przynajmniej na jednym etapie muszą mieć możliwość spotkania się na specjalnie do tego celu powołanych zebraniach [Kębłowski 2014: 13]. W Standardach procesów budżetu partycypacyjnego w Polsce zapisano, że jedną z kluczowych zasad jest zapewnienie mieszkańcom przestrzeni do deliberacji. Budżet partycypacyjny nie powinien być jedynie plebiscytem dotyczącym wyboru konkurencyjnych zadań. Wybór poszczególnych projektów powinien być efektem debaty mieszkańców na temat ich potrzeb i priorytetów. Kryterium to w odniesieniu do łódzkiego budżetu obywatelskiego nastręcza pewnych trudności analityczno-metodologicznych. We wszystkich dotychczas zrealizowanych w Łodzi edycjach zorganizowano spotkania z mieszkańcami. Organizację tych spotkań Urząd Miasta Łodzi zlecał zwykle jednej z łódzkich organizacji pozarządowych, co prawdopodobnie miało zagwarantować ich profesjonalną realizację oraz stanowić pewien bufor gwarantujący efektywną komunikację między mieszkańcami a urzędnikami. Jednak spotkania te jedynie w znikomym stopniu opierały się na żywej debacie pomiędzy uczestniczącymi w nich

\footnotetext{
${ }^{14} \mathrm{http}: / /$ budzet.dlalodzi.info/ - na stronie można znaleźć informacje o I, II i III edycji łódzkiego budżetu obywatelskiego.
} 
mieszkańcami ${ }^{15}$. Zwykle ograniczały się do przedstawienia informacji na temat procedury oraz udzieleniu wsparcia $\mathrm{w}$ przygotowaniu formularzy. Pomimo pewnych doświadczeń w zakresie stosowania technik partycypacyjnych w postaci deliberacji [por. Krzewińska 2014] spotkania konsultacyjne w łódzkiej społeczności charakteryzują się raczej niskim poziomem akulturacji i malejącą w kolejnych edycjach budżetu frekwencją. Z udostępnionych przez Stowarzyszenie „Topografie” danych ${ }^{16}$ wynika, że w roku 2013 w 36 zorganizowanych spotkaniach informacyjno-promocyjnych dla mieszkańców osiedli udział wzięło w sumie 514 osób, co daje średnio 14,3 osoby na każde spotkanie. W ramach I edycji budżetu obywatelskiego zrealizowano także 5 spacerów badawczych, każdy w jednej łódzkiej dzielnicy, w sumie w inicjatywach tych wzięło udział 16 osób, co daje średnią na poziomie 3,2 osoby na jeden spacer. Nieco gorzej sytuacja wyglądała w kolejnym roku, w 36 spotkaniach informacyjno -promocyjnych udział wzięły już tylko 224 osoby, co daje średnio 6,2 osoby na spotkanie ${ }^{17}$. Podsumowując, w ramach łódzkiego budżetu obywatelskiego zapewniono możliwość i przestrzeń do dyskusji, którą łodzianie wykorzystali tylko w niewielkim stopniu. Warto w tym miejscu rekomendować poszukiwanie innych możliwości dotarcia i zachęcenia mieszkańców do uczestniczenia w spotkaniach dotyczących rozwoju ich osiedli. Czasami zmiana ich formy bądź wykorzystanie istniejących sieci powiązań mieszkańców mogłyby usprawnić cały proces.

Z zasadą czwartą ściśle wiąże się również piąte kryterium budżetu partycypacyjnego, tj. wspieranie aktywności mieszkańców. W publikacji Standardy procesów budzetu partycypacyjnego w Polsce [2015: 10] regułę tę opisano w następujący sposób: „Proces budżetu partycypacyjnego powinien opierać się na aktywności samych mieszkańców i stwarzać im jak najwięcej okazji i przestrzeni do współdziałania, m.in. w dyskusji o lokalnych potrzebach, współpracy przy przygotowywaniu projektów, rozmowie o priorytetach wydatkowych i budowaniu poparcia dla poszczególnych propozycji na etapie wyboru projektów do realizacji”. Odnosząc się do powyższego opisu oraz doświadczeń związanych z realizacją łódzkiego budżetu obywatelskiego, można stwierdzić, że podejmowane w jego ramach działania mają na celu wspieranie aktywności mieszkańców, aczkolwiek sposobności te nie są do końca wykorzystywane przez lokalną społeczność. Być może znaczenie ma tutaj określone podejście do tej formy partycypacji społecznej. Jak wskazał Kacper Pobłocki [2013] we wstępie do książki Marcusa Miessena Partycypacja to gra podwójnie pozorowana, „po pierwsze władze dają mieszkańcom do dyspozycji jeden procent budżetu miasta (lub mniej) właśnie po to, by móc w większym spokoju dysponować pozostałymi dziewięćdziesięcioma dziewięcioma procentami. Mają w ten sposób gotową odpowiedź na zarzut, że nie liczą się z potrzebami mieszkańców. Organizują konsultacje

${ }^{15}$ Jeden z autorów współmoderował dyskusje z mieszkańcami we wszystkich dotychczasowych edycjach budżetu obywatelskiego.

${ }^{16}$ Informacje na temat frekwencji w spotkaniach realizowanych w ramach budżetu obywatelskiego zawarto również w artykule K. Brzezińskiego [2016].

${ }^{17}$ Autorzy uzyskali dostęp do frekwencji w trakcie spotkań z I i II edycji budżetu obywatelskiego. 
społeczne przy uchwalaniu miejscowych planów zagospodarowania przestrzennego, ale najczęściej konsultuje się już w zasadzie gotowe projekty, a spotkania te służą jedynie jako wentyl bezpieczeństwa dla społecznego niezadowolenia" [Pobłocki 2013: 13]. Odnosząc się do powyżej przytoczonych słów, niski poziom obywatelskiego zaangażowania mieszkańców może się wiązać z brakiem wiary w możliwość wywarcia istotnego wpływu na zmianę.

Ostatnim z wymienianych kryteriów jest postulat myślenia długofalowego. Wprowadzenie budżetu partycypacyjnego powinno być poprzedzone pogłębionym namysłem, a sama procedura być postrzegana jako cykliczny mechanizm współdecydowania przez mieszkańców o funkcjonowaniu danej społeczności [Standardy procesów budżetu partycypacyjnego w Polsce 2015]. Odnosząc się do łódzkiego budżetu obywatelskiego, warto przypomnieć, że jego procedura została wypracowana przez wieloosobowy i interdyscyplinarny zespół [Gałecki 2013], co może dowodzić uwzględnienie różnych punktów widzenia i perspektyw. Ilość i zakres zrealizowanych do tej pory edycji łódzkiego budżetu obywatelskiego wskazuje, że przez decydentów miejskich jest on traktowany jako trwały element polityki miejskiej.

Tabela 1. Realizacja zasad budżetowania partycypacyjnego w ramach łódzkiego budżetu obywatelskiego

\begin{tabular}{|l|l|}
\hline \multicolumn{1}{|c|}{ Kluczowe zasady budżetu partycypacyjnego } & \multicolumn{1}{c|}{ Łódzki budżet obywatelski } \\
\hline Wiążący wynik procedury & Tak \\
\hline Przejrzystość i jawność procedury & Tak \\
\hline Otwartość i inkluzywność procesu & Tak \\
\hline $\begin{array}{l}\text { Zapewnienie przestrzeni do deliberacji (debaty) z udziałem miesz- } \\
\text { kańców }\end{array}$ & Tak/Nie \\
\hline Wspieranie aktywności mieszkańców & Tak/Nie \\
\hline Myślenie długofalowe & Tak \\
\hline
\end{tabular}

Źródło: opracowanie własne.

\section{ZAKOŃCZENIE}

Zmiana modelu zarządzania publicznego w kierunku zwiększenia ich interaktywnych form jest dostrzegana nie tylko na poziomie władzy państwowej, ale staje się również, a może przede wszystkim jest widoczna na poziomie samorządów lokalnych. Idea local governance wydaje się w tym ujęciu kwintesencją samorządności polegającej na zaangażowaniu różnych podmiotów, w tym indywidualnych obywateli, działających w imię dobra wspólnego. Autorytarny, oparty na sztywnych biurokratycznych zasadach system zarządzania lokalną przestrzenią coraz częściej jest zastępowany jego nowymi formami opartymi na zaangażowaniu różnych aktorów zainteresowanych lokalnymi sprawami. Podmioty te stają się nie tylko odbiorcami efektów polityki publicznej gminy, lecz także jego aktywnymi kreatorami. Proces współzarządzania na poziomie lokalnym jest realizowany przy wykorzystaniu różnych metod i mechanizmów. 
Wydaje się, iż pozytywnym przykładem wykorzystania takiego mechanizmu, spełniającym istotne warunki z punktu widzenia idei local governance, jest budżetowanie partycypacyjne. Cieszące się coraz większą popularnością w polskich samorządach skłania również do bardziej krytycznego oglądu wykorzystywanych przy jego realizacji procedur. Niniejszy tekst był próbą skonfrontowania przyjętych i powszechnie akceptowanych kryteriów realizacji budżetów obywatelskich w Polsce ze stopniem ich rzeczywistej realizacji w wybranym samorządzie lokalnym. Wybór Łodzi i jej budżetu obywatelskiego jest nieprzypadkowy, często bowiem jest pokazywany jako pozytywny przykład, a nawet wzór dla innych samorządów.

Dokonawszy jakościowej analizy stopnia respektowania zasad budżetowania partycypacyjnego w łódzkim budżecie, należy uznać, iż opiera się on w znacznym stopniu na przyjętych zasadach. Największym jednak problemem dotyczącym nie tylko Łodzi jest poziom i zakres rzeczywistego zaangażowania mieszkańców w jego realizację. Najsłabszym ogniwem realizacji opisywanego przedsięwzięcia jest jego wymiar konsultacyjny. Zaangażowanie potwierdzone liczbą zgłaszanych propozycji oraz frekwencją wyborczą należy ocenić pozytywnie. Jednak uczestnictwo w konsultacyjnej (opartej na spotkaniach z mieszkańcami) fazie realizacji budżetu pozostawia wiele do życzenia. Nie należy jednak w tym kontekście w pełni negatywnie oceniać warunków i sposobności stworzonych przez lokalne władze, które, jak starano się wykazać, proponują różne możliwości wspólnej dyskusji. Wydaje się, iż potrzeba nieco czasu, aby w społeczności pojawiła się świadomość nie tylko uczestnictwa w akcie wyborczym, lecz także mobilizacja do aktywnego uczestnictwa w spotkaniach konsultacyjnych, a w dalszej kolejności deliberatywnych, które często są postulowane w literaturze przedmiotu dotyczącej refleksji nad budżetami partycypacyjnym [por. Martela 2013]. Kolejnym problemem, który poniekąd wiąże się z wyżej wspomnianą mobilizacją, jest konieczność posiadania pewnych kompetencji obywatelskich. Jak zauważyła Marta Siciarek [2014], niektóre narzędzia partycypacyjne, w tym m.in. budżet obywatelski, wymagają określonych kompetencji i są kierowane w głównym stopniu do osób aktywnych, wykształconych i obecnych w przestrzeni publicznej, faworyzując de facto tę kategorię społeczną. Nie ulega wątpliwości, że nie każdy łodzianin spełnia te kryteria. Wydaje się zatem, że wprowadzenie modelu governance w polskich samorządach będzie wymagać jeszcze dużo czasu oraz pracy, zarówno po stronie włodarzy, jak i samych obywateli.

\section{BIBIOGRAFIA}

Barber, B. 1997. Dżihad kontra McŚwiat, Muza SA, Warszawa.

Bluj, A., Stokłuska, E. 2015. Budżet partycypacyjny (obywatelski) krok po kroku. Poradnik dla praktyków, Fundacja Pracownia Badań i Innowacji Społecznych „Stocznia”, Warszawa.

Brzeziński, K. 2016. Między biernościa a aktywnościa obywatelska w kontekście tódzkiego budżetu obywatelskiego, „Studia Miejskie”, nr 21.

CBOS 2011, Aktywność spoleczna Polaków - poziom zaangażowania i motywacje, BS/62/2011. 
CBOS 2012, Potencjat społecznikowski i zaangażowanie Polaków w wolontariat, BS/23/2012.

Dias, N. 2014. 25 years of Participatory Budgets in the world: a new social and political movement?, [w:] Hope for Democracy - 25 years of participatory budgeting worldwide, N. Dias (red.), In Loco Association, Sao Bras De Alportel.

Gałecki, A. 2013. Budżet obywatelski w Mieście Łodzi, [w:] Partycypacja społeczna w Polsce. Atlas dobrych praktyk, M. Ćwiklicki, M. Frączek (red.), Fundacja Gospodarki i Administracji Publicznej, Kraków.

Gerwin, M. 2012. Odkrywanie demokracji, [w:] Miasto w działaniu. Zrównoważony rozwój z perspektywy oddolnej, P. Filar, P. Kubicki (red.), Instytut Obywatelski, Warszawa.

Gliński, P., Palska, H. 1997. Cztery wymiary aktywności obywatelskiej, [w:] Elementy nowego ładu, H. Domański, A. Rychard (red.), IFiS PAN, Warszawa.

Gliński, P. 2006. Trzeci sektor w Polsce. Dylematy aktywności, [w:] Czy spoleczny bezruch? O spoteczeństwie obywatelskim i aktywności we wspótczesnej Polsce, M. Nowak, M. Nowosielski (red.), Instytut Zachodni, Poznan.

Haratyk, K. 2009. Pomiędzy globalizacją i demokracja. Przemiany koncepcji demokracji w epoce zaniku polityki, „Kultura-Historia-Globalizacja”, nr 5.

Kębłowski, W. 2013. Budżet partycypacyjny. Krótka instrukcja obstugi, Instytut Obywatelski, Warszawa.

Kębłowski, W. 2014. Budżet partycypacyjny. Ewaluacja, Instytut Obywatelski, Warszawa.

Kraszewski, D., Mojkowski, K. 2014. Budżet obywatelski w Polsce, Fundacja im. Stefana Batorego, Warszawa.

Krzewińska, A. 2014. Dyskusje grupowe oparte na deliberacji jako forma partycypacyjnego sposobu podejmowania decyzji, [w:] Dialog obywatelski. Formy, mechanizmy, bariery i perspektywy rozwoju, M.W. Sienkiewicz, M. Sidor (red.), Wydawnictwo Fundacji Centrum Rozwoju Lokalnego, Lublin.

Lewenstein, B. 2010. Między rządzeniem a wspótrządzeniem. Obywatelskie modele rozwoju społeczności lokalnej, [w:] Partycypacja społeczna i aktywizacja w rozwiąywaniu problemów społeczności lokalnych, B. Lewenstein, J. Schindler, R. Skrzypiec (red.), Wydawnictwo Uniwersytetu Warszawskiego, Warszawa.

Luterek, M. 2010. E-government. Systemy informacji publicznej, Wydawnictwa Akademickie i Profesjonalne, Warszawa.

Łukomska-Szarek, J., Włóka, M. 2013. Od Local Government do Local Governance - wybrane problemy zarzadzania publicznego jednostkami podsektora samorzadowego, [w:] Wybrane procesy zarzadzania w przedsiębiorstwach i instytucjach publicznych, D. Wielgórka (red.), Sekcja Wydawnictw Wydziału Zarządzania Politechniki Częstochowskiej, Częstochowa.

Łukomska-Szarek, J. 2014. Budżetowanie partycypacyjne jako instrument wspótzarzqdzania sfera publiczna, „Nierówności Społeczne a Wzrost Gospodarczy”, nr 4.

Marks-Krzyszkowska, M. 2013. Zarządzanie publiczne na poziomie lokalnym-geneza, główni aktorzy i ich zaangażowanie, „Studia Prawno-Ekonomiczne”, nr LXXXVIII (88).

Marks-Krzyszkowska, M. 2016. Zarzadzanie publiczne - istota $i$ wybrane koncepcje, „Acta Universitatis Lodziensis. Folia Sociologica", nr 56.

Martela, B. 2013. Budżet partycypacyjny w Polsce - wdrożenie i perspektywy, „Władza Sądzenia”, nr 2.

Michalska-Żyła, A. 2015. Między aktywnościa a biernościa. Postawy obywatelskie mieszkańców średnich miast, [w:] Obywatele wobec kryzysu: uśpieni czy innowatorzy?, W. Misztal, A. Kościański, G. Chimiak (red.), IFiS PAN, Warszawa.

Oramus, M. 2015. Model wspótzarządzania (governance) i problemy dotyczace jego wdrażania w administracji publicznej, „Rocznik Administracji Publicznej”, nr 1.

Miessen, M. 2013. Koszmar partycypacji, Fundacja Bęc Zmiana, Warszawa.

Pobłocki, K. 2013. Prawo do odpowiedzialności, [w:] M. Miessen, Koszmar partycypacji, Fundacja Bęc Zmiana, Warszawa.

Putnam, R. 2008. Samotna gra w kręgle, Wydawnictwo Akademickie i Profesjonalne, Warszawa.

Siciarek, M. 2014. Narzędzia partycypacyjne nie gwarantuja partycypacji, [w:] Miasto na żądanie. Aktywizm, polityka miejska, doświadczenia, Ł. Bukowiecki, M. Obarska, X. Stańczyk (red.), Wydawnictwo Uniwersytetu Warszawskiego, Warszawa. 
Sintomer, Y., Herzberg, C., Rocke, A. 2014. Transnational Models of Citizen Participation: The Case of Participatory Budgeting, [w:] Hope for Democracy - 25 years of participatory budgeting worldwide, N. Dias (red.), In Loco Association, Sao Bras De Alportel.

Standardy procesów budżetu partycypacyjnego w Polsce, 2014, Fundacja Pracownia Badań i Innowacji Społecznych „Stocznia”, Warszawa.

Stypułkowski, W. 2012. Aktywność obywatelska - pojęcie, pomiar i jej wpływ na rozwój regionalny, „Zeszyty Naukowe WSEI”, nr 5.

Sułek, A. 2011. Doświadczenie, działania dla społeczności i kompetencje obywatelskie, [w:] Diagnoza społeczna 2011. Warunki i jakość życia Polaków. Raport, J. Czapiński, T. Panek (red.), Centrum Rozwoju Zasobów Ludzkich, Warszawa.

Suwaj, P.J. 2010. Udzial spoleczeństwa $w$ decydowaniu publicznym - oblicza partycypacji społecznej w polityce publicznej w zakresie inwestycji drogowych, „Samorząd Terytorialny”, nr 1-2.

Zarządzenie 3971/VI/13 prezydent miasta Łodzi z dnia 2 kwietnia $2013 \mathrm{w}$ sprawie przeprowadzenia konsultacji społecznych dotyczących budżetu obywatelskiego na rok 2014, http://bip.uml.lodz.pl/_plik. php?plik=uchwaly/pm/VI_3971.PDF (dostęp: 07.05.2016).

Zarządzenie 3837/VI/14 prezydent miasta Łodzi z dnia 5 marca $2014 \mathrm{w}$ sprawie przeprowadzenia konsultacji społecznych dotyczących budżetu obywatelskiego na rok 2015, http://bip.uml.lodz.pl/_plik. php?plik=uchwaly/pm/VI_5837.PDF (dostęp: 07.05.2016).

Zarządzenie 644/VII/15 prezydent miasta Łodzi z dnia 17 marca $2015 \mathrm{w}$ sprawie przeprowadzenia konsultacji społecznych dotyczących budżetu obywatelskiego na rok 2016, http://uml.lodz.pl/budzet_obywatelski/budzet_obywatelski_na_2016/aktualnosci/ (dostęp: 07.05.2016).

Zarządzenie 2914/VII/16 prezydent miasta Łodzi z dnia 19 lutego $2016 \mathrm{w}$ sprawie przeprowadzenia konsultacji społecznych dotyczących budżetu obywatelskiego na rok 2017, http://uml.lodz.pl/budzet_obywatelski/2017/ (dostęp: 07.05.2016).

\section{PARTICIPATORY BUDGET AS A MECHANISM OF CO-MANAGEMENT OF THE CITY}

Abstract: One of the solutions to deal with the current crisis of democracy might be actions increasing the socio-political participation of citizens. These actions (solutions) should be based on assumptions of governance concept. An example of the method (mechanism) involving citizens in the process of co-decision and increasing their engagement in shaping urban policy is participatory budget. This method is gaining more and more popularity in Polish local governments. However, the question is, to what extent Polish participatory budgets are really participatory? Are they based on real and active participation of residents of the cities? This article attempts to answer these questions.

Keywords: participatory budget, public management, governance, civic activity

\section{BIOGRAMY}

Agnieszka Michalska-Żyła, dr nauk humanistycznych w zakresie socjologii, adiunkt w Katedrze Socjologii Wsi i Miasta Uniwersytetu Łódzkiego. Jej zainteresowania naukowe są związane z socjologią miasta i koncentrują się na problematyce więzi społecznych i terytorialnych, partycypacji obywatelskiej mieszkańców, rozwoju i wizerunku miast (szczególnie poprzemysłowych), oraz jakości życia i zamieszkiwania. Kontakt e-mail: amichalska-zyla@wp.pl. 
Kamil Brzeziński, socjolog, badacz i asystent w Katedrze Socjologii Wsi i Miasta Uniwersytetu Łódzkiego. Współrealizator i wykonawca wielu projektów badawczych z zakresu problematyki miejskiej. Poza pracą na uczelni związany również z łódzkimi organizacjami pozarządowymi, z którymi współpracuje przy realizacji licznych projektów związanych z partycypacją i konsultacjami społecznymi. Kontakt e-mail: kamilbrzezinski84@gmail.com. 